\title{
https://doi.org/10.46813/2021-131-025 \\ DISTRIBUTION OF 0.2...4.5 keV PLASMA IONS IN SET OF U-2M DISCHARGES
}

\author{
A.S. Slavnyj, R.O. Pavlichenko, A.N. Shapoval, M.N. Makhov, and M.B. Dreval \\ Institute of Plasma Physics, National Science “Kharkov Institute of Physics and Technology”, \\ Kharkiv, Ukraine
}

\section{E-mail: slavny@kipt.kharkov.ua}

\begin{abstract}
Charge exchange (CX) neutral fluxes were measured by neutral particle analyzer (NPA) in plasma discharges sustained by the W7-X-like radio frequency (RF) antenna in the Uragan-2M (U-2M) stellarator. CX fluxes in pure hydrogen discharge $\left(\mathrm{B}_{0}=0.36 \mathrm{~T}, f=4.926 \mathrm{MHz}\right)$ in stellarator configuration (effective perpendicular ion temperature $\left.\mathrm{T}_{\perp} \approx 450 \mathrm{eV}\right)$ is less energetic in comparison with $\mathrm{U}-2 \mathrm{M}$ hybrid configuration $\left(\mathrm{T}_{\perp} \approx 800 \mathrm{eV}\right)$. RF discharge in stellarator configuration with helium and hydrogen mixture $\left(\mathrm{B}_{0}=0.351 \mathrm{~T} ; \mathrm{f}=5.156 \mathrm{MHz}\right.$, $\mathrm{P}=6 \cdot 10^{-4}$ Torr $)$ shows more energetic $\mathrm{CX}$ fluxes $\left(\mathrm{T}_{\perp} \approx 1 \mathrm{keV}\right)$. The ion cyclotron frequency distribution across the $\mathrm{U}-2 \mathrm{M}$ plasma has been studied numerically. These calculations are accompanied by direct measurement of the RF frequency by magnetic sensor. The ion cyclotron frequency is present in plasma bulk of all discharges under consideration.
\end{abstract}

PACS: 52.55.Hc; 52.70.La

\section{INTRODUCTION}

Experimental study of ion heating mechanisms in the radio frequency $(\mathrm{RF})$ range close to the ion cyclotron frequency (ICRF) can provide important information for $\mathrm{RF}$ plasma heating and RF wall conditioning [1-3] at these frequencies $\left(\omega \lesssim \omega_{\mathrm{ci}}\right)$. Time, space and energy distribution of $0.5 \ldots 4.5 \mathrm{keV}$ ions in the Uragan-3M (U-3M) low-density frame-type antenna (FTA) [4] RF plasma discharges in the RF frequency range close to the ion cyclotron frequency (ICRF) case were reported recently [5]. According to this article a fast ion energy increase was observed in the plasma build-up stage; the ion energy distribution was close to the Maxwellian one in the energy range of $0.4 \ldots 2.5 \mathrm{keV}$; ion temperature $\mathrm{T}_{\mathrm{i}}=300 \ldots 600 \mathrm{eV}$ in this energy range was determined. It has been concluded the following: the RF energy deposition into the ions is direct due to the negligible ion-electron energy exchange; a significant RF energy contribution into the ions at the plasma edge is expected but the energetic ions are presented in the plasma bulk as well. A wide range of possible RF ion heating mechanisms was mentioned in the article, but an accurate description of the U-3M ion heating is still an open question. In Ref. [6] the fast $(\leq 0.5 \mathrm{~ms})$ decay of vertical and tangential $\mathrm{CX}$ fluxes after turning off the U-3M FTA RF heating power was reported. It has been concluded that the U-3M energy confinement time for $0.5 \ldots 4.5 \mathrm{keV}$ ions is less than $0.5 \mathrm{~ms}$ in the low-density $\left(\mathrm{n}_{\mathrm{e}} \approx(1 \ldots 4) \cdot 10^{12} \mathrm{~cm}^{-3}\right)$ discharges. According to this article no difference between the confinement of the ion energy component parallel to the magnetic field and the confinement of that one perpendicular to the magnetic field was observed in U-3M. It has been noticed that the ion cooling through $\mathrm{CX}$ collisions with neutrals sustains a substantial channel of the $0.5 \ldots 4.5 \mathrm{keV}$ ion energy loss in the U-3M torsatron. In current work we are presenting first measurements of the CX fluxes In Uragan 2-M (U-2M) stellarator in W7-X - like antenna discharges.

$\mathrm{U}-2 \mathrm{M}$ is a middle size stellarator with sixteen additional toroidal magnetic field coils [7, 8], they are uniformly arranged along the torus length. It utilizes the $(\mathrm{m}=2$ periods in the toroidal direction; $1=2$ (helical coils)) torsatron configuration scheme with eight poloidal magnetic field coils. The major torus radius is $\mathrm{R}_{0}=1.7 \mathrm{~m}$, the average last closed flux surface minor radius is $\overline{\mathrm{a}} \approx 0.2 \mathrm{~m}$. A top view of the $\mathrm{U}-2 \mathrm{M}$ stellarator is shown in Fig. 1.

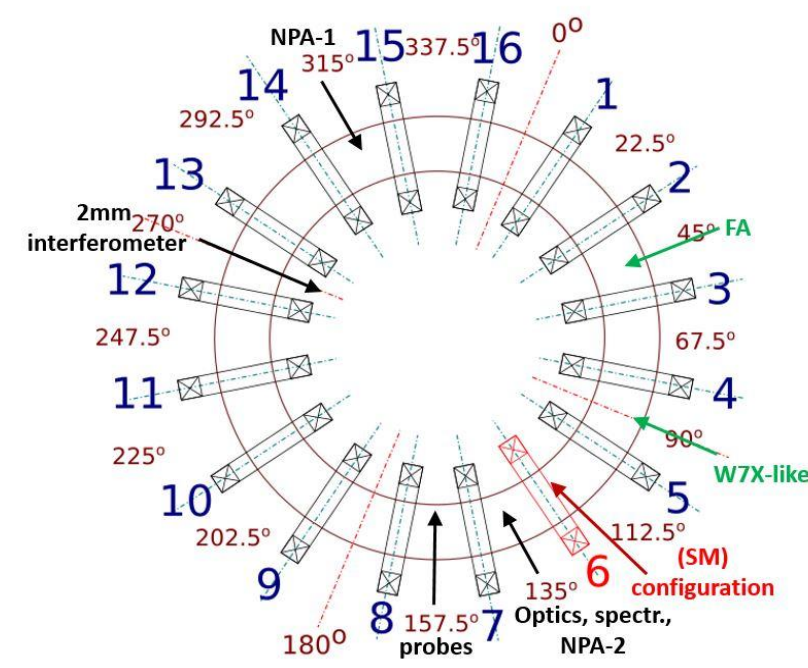

Fig. 1. Top view of the $U-2 M$ and diagnostics arrangement (schematic). The position of the primary poloidal crossection of the plasma (elliptical shaped, orientated vertically, horizontally, and slanted) are indicated by degrees' numbers. RF heating antenna and some diagnostics are also presented on a schema.

Switched off TF\#6 coil for stellarator-mirror hybrid configuration indicated as (SM) 


\section{U-2M MAGNETIC CONFIGURATIONS}

The U-2M magnetic system allows to operate in several magnetic configurations. Under "normal" operating conditions the toroidal field coils create an additional toroidal magnetic field. Its direction coincides with the direction of a toroidal magnetic field produced by helical magnetic coils. The shape of the magnetic surfaces is governed by two parameters: $\mathrm{K}_{\varphi}=\mathrm{B}_{\varphi} / \mathrm{B}_{0}$ and $\mathrm{B}_{\perp} / \mathrm{B}_{0}$. For experiments under consideration the range of those parameters are as follows: $0.29<\mathrm{K}_{\varphi}<0.33 ; 1.2 \%<\mathrm{B}_{\perp} / \mathrm{B}_{0}<1.85 \%$. This is so-called stellarator configuration. Fig. 2 shows the numerically calculated magnetic surfaces for the U-2M with following configurational parameters: $\mathrm{B}_{0}=0.288 \mathrm{~T}, \mathrm{~K}_{\varphi}=0.319, \mathrm{~B} \perp \mathrm{B}_{0}=1.2 \%$. It was done following the framework introduced in the Ref. [11, 12]. For all configurations the magnetic field is calculated using the Biot-Savart law code [12]), where influence of current feeds and detachable joints of the helical winding is taken into account by the approach analogous to that in Ref. [13].
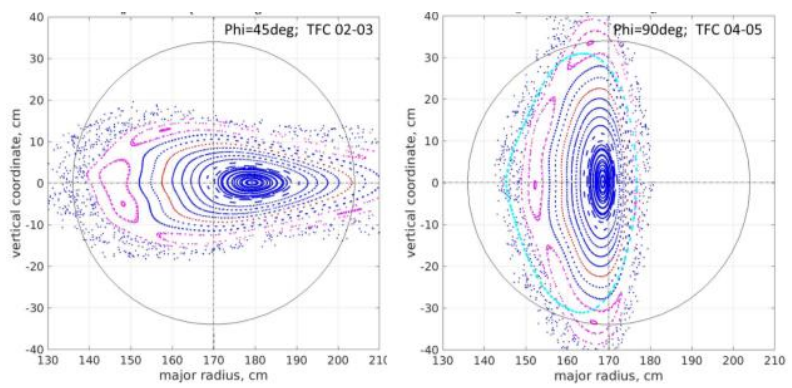

Fig. 2. The magnetic surfaces of two principal crossection for the stellarator configuration (operational parameters: $B_{0}=0.288 T, K_{\varphi}=0.319$, $B \perp / B O=1.2 \%$ ). At the crossection Phi=90 deg (right subfigure) TSA ICRF heating antenna is installed, FA antenna installed at Phi=22.5 deg crossection (not shown)

Integration of the magnetic field lines is performed for the intervals corresponding to 250 turns around the major axis of the torus. Cross-sections of the magnetic surfaces obtained as the results of these computations are presented in Figs. 2, 3.
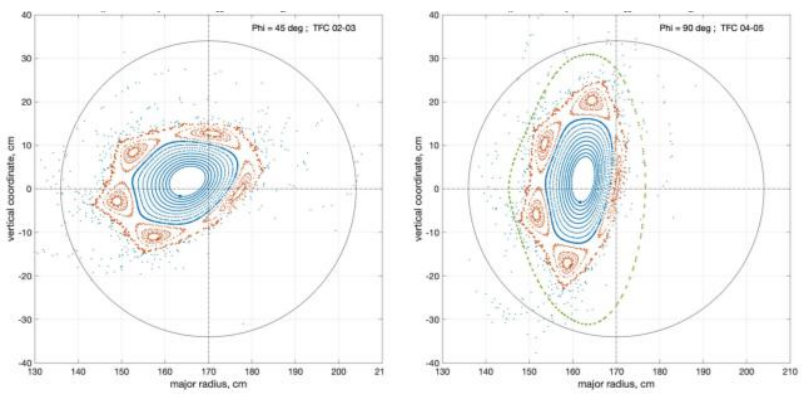

Fig. 3. The magnetic surfaces of two principal crossection for the SM configuration (operational parameters: $\left.B_{0}=0.385 T, K_{\varphi}=0.228, B_{\perp} / B_{0}=1.1\right)$. At the crossection Phi=90 deg (right subfigure) TSA

ICRF heating antenna is installed, FA antenna installed at Phi=22.5 deg crossection (not shown)
Part of the U-2M stellarator experimental programme is focused on investigation of the "stellarator-mirror hybrid" (SM) concept. The magnetic configuration of a stellarator with an embedded magnetic mirror is arranged in this device by switching off one toroidal coil (TC). For that same type of numerical calculations of the magnetic surfaces were performed. In the SM experiments and simulations which are presented here the TC\#6 was switched off (see Fig. 3). The main goal of the conducted calculation is to find the possibility of existence of closed magnetic surfaces in the U-2M torsatron is analyzed in case of zero current in one coil of the set of the toroidal field coils. It follows from the results that a removal of one of the toroidal field coils leads to a significant reduction in the size of outermost magnetic surfaces, although such a decrease in the

$\mathrm{U}-2 \mathrm{M}$ operating modes can be acceptable.

\section{EXPERIMENTAL CONDITIONS}

W7-X-like antenna [9] is used for the plasma production and heating in present experiments. This antenna is similar in shape and differs from $\mathrm{W} 7-\mathrm{X}$ one mainly by the smaller size. Unshielded W7-X-like antenna is surrounded by the SOL plasma. The $\mathrm{U}-2 \mathrm{M}$ is equipped with two passive single-energy channel electrostatic small-angle $30^{\circ} \mathrm{CX}$ neutral particle analyzers (NPA) similar to that in details described in the Ref. $[5,10]$, the difference is that our NPAs operate without the mass separation. Sweeping NPA operating modes [5] was used. A triangular $2 . .5 \mathrm{~ms}$ analyzing voltage shape was applied to the electrostatic plates in order to carry out fast $(2 \ldots .5 \mathrm{~ms})$ measurement of the energy distribution using the single-energy channel analyzer. An additional $15 \mathrm{keV}$ acceleration of ions after the electrostatic separation and ion-electron conversion allows one to suppress the variation of the NPA collector sensitivity with energy [10]. One NPA is located near W7-X-like antenna and another far from the antennas. NPAs are separated toroidally by about $180^{\circ}$. Nitrogen is used in the NPA gas stripping cell. We should note that in the $10 \ldots 100 \mathrm{eV}$ energy range the hydrogen atom stripping on the nitrogen gas target cross-section is dropping by 5 orders of magnitude, a NPA signal is comparable with a noise; the energy dependence is not linear in the logarithmic scale. Therefore, a low-energy part of the distribution cannot be accurately considered. Thus, we cannot measure an absolute ion temperature, but can analyze only the ion distribution range above $200 \ldots 500 \mathrm{eV}$. Due to the lack of the low-energy part of the ion distribution data, our analysis is fractional and we do not know whether the NPA temperature is dominant or such ions contribute a few percent to the total ion energy distribution (if the low- energy part contribution is dominant).

NPAs are located in different toroidal cross-sections. One NPA with fixed line of sight crossing plasma center and another with variable line of sight angle (for space distribution). The perpendicular ion energy distribution is measured along almost horizontal lines. A collecting area of this NPA is approximately cylindrical with about $3 \mathrm{~cm}$ in diameter. A long NPA-plasma distance $(\approx$ 
$2.5 \mathrm{~m}$ ) allows one to neglect the divergence of the collecting area diameter and possible variation of the space resolution with neutrals energy. A high NPA energy resolution $\Delta \mathrm{E} / \mathrm{E} \approx 5 \%$ was selected by its hardware, confirmed by a monoenergetic beam NPA calibration, and was used in the present work. Variations of line-of-sight angle allow us measurement of CX flux distribution from plasma center to lower outer plasma part. Very high $\mathrm{CX}$ fluxes in U-2M RF discharges give us a possibility to use the analog regime for obtaining the NPA signal. The NPA signal integration time was $0.1 \mathrm{~ms}$, and its sampling rate was of about $50 \mathrm{kS} / \mathrm{s}$.

\section{EXPERIMENTAL RESULTS}

Considerable CX flux in $0.5 \ldots 4.5 \mathrm{keV}$ energy range has been observed in various U-2M discharges. The fraction of these energetic ions strongly depends on the discharge conditions. The dominant role of the ion cyclotron zone for fast ions production has been observed in U-3M [5]. In present work we are studying three types of the U-2M discharges: pure hydrogen discharges in stellarator and hybrid configurations and hydrogen-helium mixture discharge in stellarator configuration. In order to highlight the role of the ion cyclotron zone we are presenting numerical calculations of the cyclotron frequency distributions for this configuration.

A first type of the U-2M discharge with substantial CX flux is the low density, pure hydrogen W7-X-like antenna discharge $\left(\mathrm{B}_{0}=0.36 \mathrm{~T}, \mathrm{RF}\right.$ generator frequency $f=4.926 \mathrm{MHz}$ ). A contourplot of the cyclotron frequencies are show in Fig. 4 for this configuration.

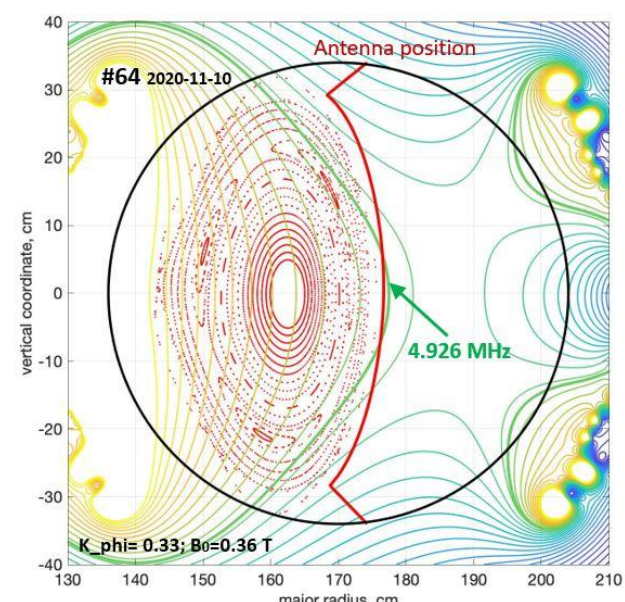

Fig. 4. The magnetic surfaces of vertical crossection (where W7-X-like RF heating antenna is installed) for the stellarator configuration (operational parameters: $\left.B_{0}=0.36 T, K_{\varphi}=0.33, B_{\perp} / B_{0}=1.2 \%\right)$. Contour lines of the ion cyclotron frequencies are plotted. Operational frequency $f=4.926 \mathrm{MHz}$ of the $R F$ generator indicated

A vacuum magnetic field is used. The $1 \%$ of the frequency step is used in this figure. As it is seen from the figure, the ion cyclotron zone corresponding to the operational frequency, preassigned to the RF generator $(\mathrm{f}=4.926 \mathrm{MHz})$ is crossing plasma edge $(\rho=1 \ldots 0.8)$. Although, the actual RF generator frequency can be different to the preassigned one. Due to simple autogenerator schematic of the U-2M RF generator, substantial impact of the plasma load can modify actual $\mathrm{RF}$ frequency. Time evolution of the RF frequency in the U-2M plasma vessel was monitored by a fast magnetic probe. Spectrogram of the magnetic sensor data in vicinity of the preassigned frequency is shown in Fig. 5.

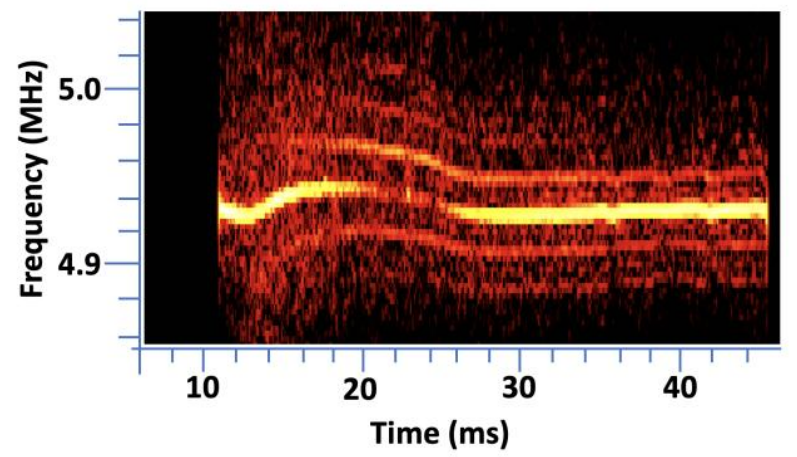

Fig. 5. Spectrogram of magnetic sensor data in vicinity of $R F$ generator frequency

Substantial variation of the preassigned frequency as well as clear frequency splitting to a set of branches are seen from Fig. 5. The amplitudes of side-band branches are comparable with the amplitude of the main frequency. The nature of this splitting is evidently related with the electronics (it is outside of the scoop of our work). Thus, the actual frequency can by $3 \ldots .5 \%$ higher in comparison with the preassigned one. The increase of RF frequency by $3 \%$ is causing the shift of the ion cyclotron zone toward the plasma center (as it is seen from the Fig. 4). Temporal evolution of the row CX signal for this type of discharge is shown in Fig. 6.

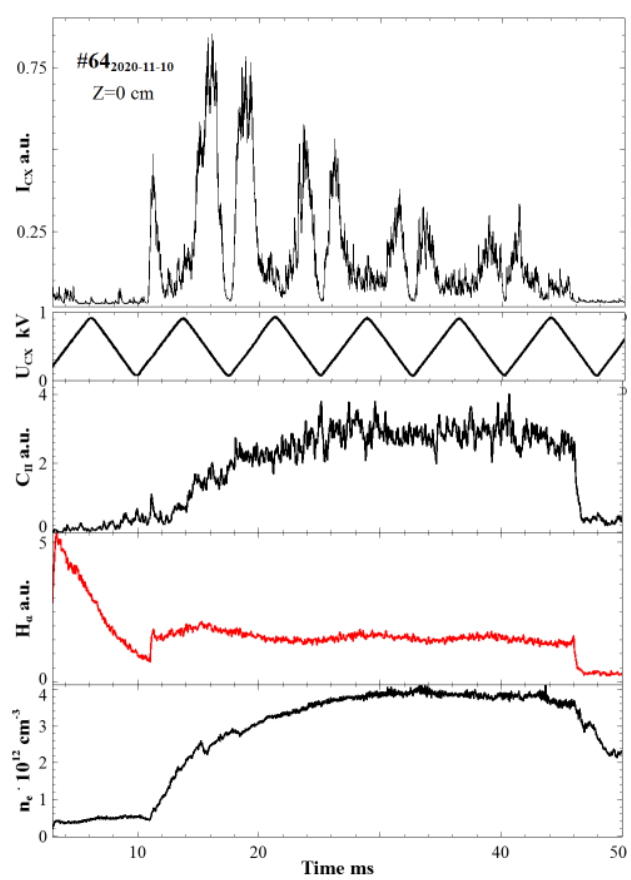

Fig. 6. Waveforms of the row NPA signal, NPA sweeping voltage, spectral lines $C_{I I}$ and $H_{\alpha}$ emission and line-averaged density in stellarator configuration pure $H$ discharge 
The energy sweeping NPA configurations is used. Row NPA collector signal, NPA sweeping voltage (the analyzing energy $E$ is $E=4.5 U_{C X}$ due to the NPA calibration $[5,10])$, spectral line and line-averaged density are shown in the figure. Substantial 0.5...4.5 keV CX flux is seen from the row NPA data. In the second type of the discharge pure hydrogen gas in hybrid configuration is used. A distribution of the ion cyclotron frequency across W7-X-like antenna crosssection (corresponding to the magnetic field minimum caused by disconnected toroidal field coil \#6) is shown in Fig. 7.

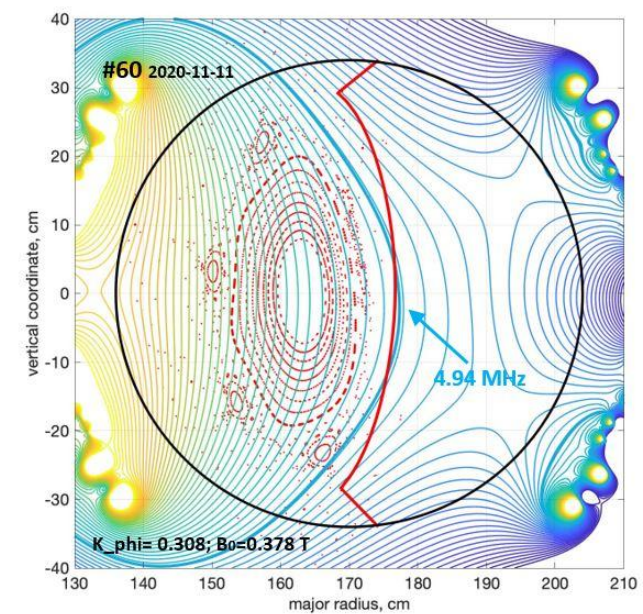

Fig. 7. The magnetic surfaces of vertical crossection (where W7-X-like RF heating antenna is installed) for the hybrid configuration (operational parameters: $B_{0}=0.378 T, K_{\varphi}=0.308, B_{\perp} / B_{0}=1.22 \%$ ). Contour lines of the ion cyclotron frequencies are plotted. Operational frequency $f=4.926 \mathrm{MHz}$ of the $R F$ generator indicated

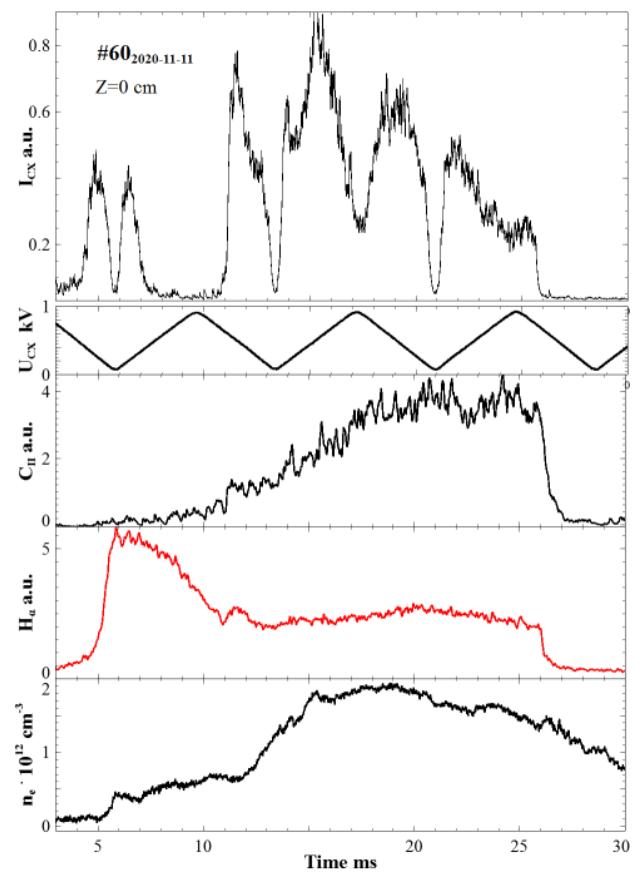

Fig. 8. Waveforms of the row NPA signal, NPA sweeping voltage, spectral lines $C_{I I}$ and $H_{\alpha}$ emission and line-averaged density in hybrid configuration pure $H$ discharge
Corresponding temporal evolution of the row $\mathrm{CX}$ signal for this hybrid discharge is shown in Fig. 8. Substantial fraction of the ions with perpendicular energies of $4.5 \mathrm{keV}$ (corresponding to $1 \mathrm{kV}$ of sweeping voltage) are observed in this type of the discharge, as it is seen from the row NPA collector signal. Reconstructions of the perpendicular energy distributions for two types of U-2M discharges are shown in Fig. 9.
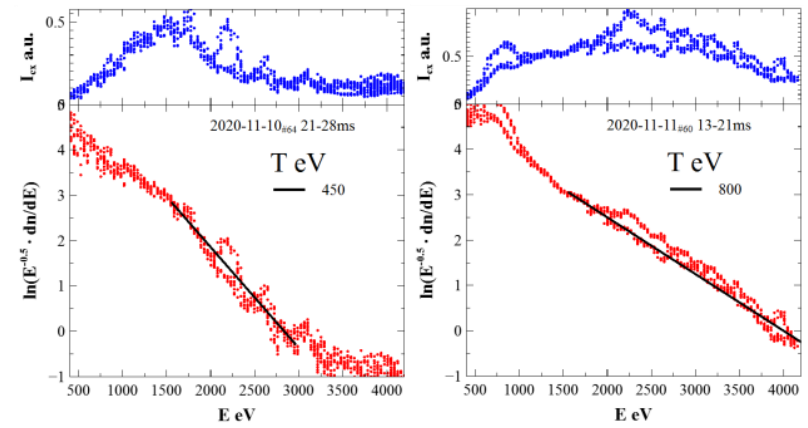

Fig. 9. Energy distribution using multiple NPA slope data in two types of pure hydrogen discharge

Formal fit of the $0.5 \ldots 4.5 \mathrm{keV}$ NPA distribution function shows, that the perpendicular ion temperature of $450 \mathrm{eV}$ in the case of the stellarator configuration is about two times lower in comparison with the hybrid one. In spite of additional possible RF absorption mechanisms in the hybrid configuration ion cyclotron zone are present in both configurations. Thus, RF absorption mechanism can be the same in spite of the different configuration. Radial distribution of the energetic ions can be estimated by vertical variation of the NPA line of sight. Dependences of $1.5 \mathrm{keV}$ CX flux amplitudes on the NPA line-of-sight vertical shift $\Delta y$ from the mid-plane are shown in Fig. 10 for the stellarator and hybrid types of the U-2M discharges.

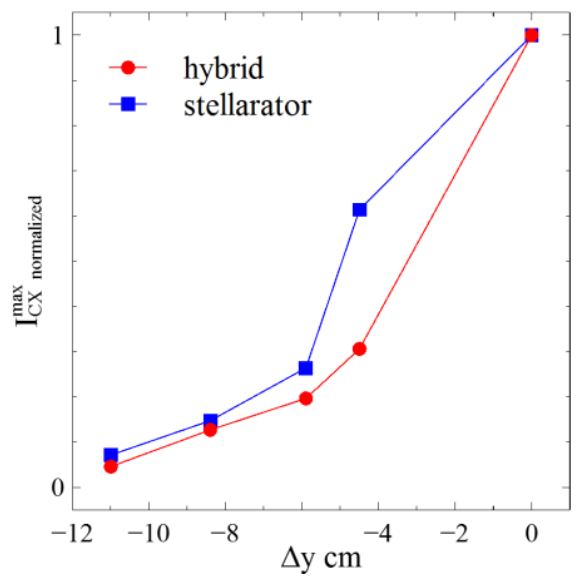

Fig. 10. Distribution of line-integrated CX flux intensity versus $\triangle y$ impact parameter of NPA line of sight in two type of discharges

These peaked line-integrated distributions indicate that the distributions of energetic ions are substantially peaked in space (in contrast to the U-3M case [5]). The third type of the discharge is the stellarator configuration discharge in the mixed hydrogen-helium plasma (\#2192019-04-10) with similar plasma conditions 
such as magnetic field, RF frequency and pressure $\left(\mathrm{B}=0.351 \mathrm{~T} ; \mathrm{f}=5.156 \mathrm{MHz}, \mathrm{P}=6 \cdot 10^{-4}\right.$ Torr $)$ [9]. The corresponding plasma shape and position of the ioncyclotron resonance for hydrogen in the W7-X-like antenna cross-section is shown in the Fig. 11.

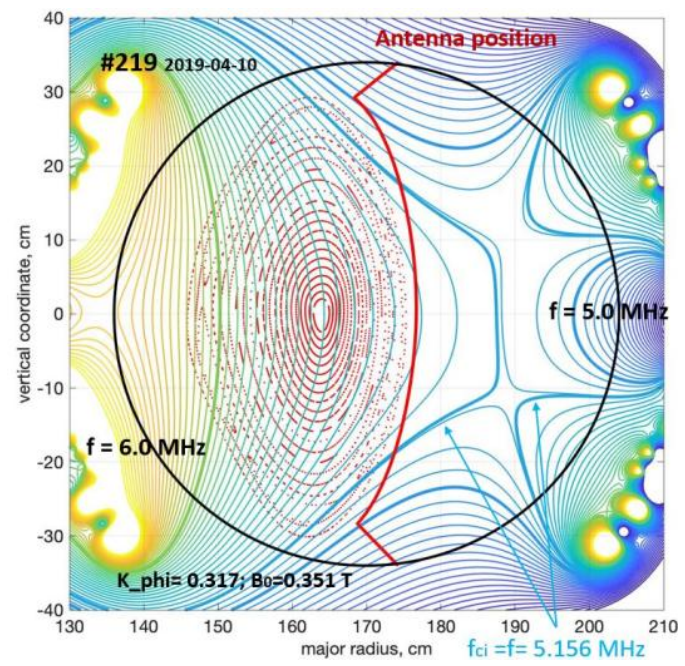

Fig. 11. The magnetic surfaces of vertical crossection

(W7-X-like RF heating antenna is installed) for the stellarator configuration (operational parameters: $\left.B_{0}=0.351 T, K_{\varphi}=0.317, B \perp / B_{0}=1.21 \%\right)$. Contour lines of the ion cyclotron frequencies are plotted. Operational frequency $f=5.156 \mathrm{MHz}$ of the $R F$ generator indicated

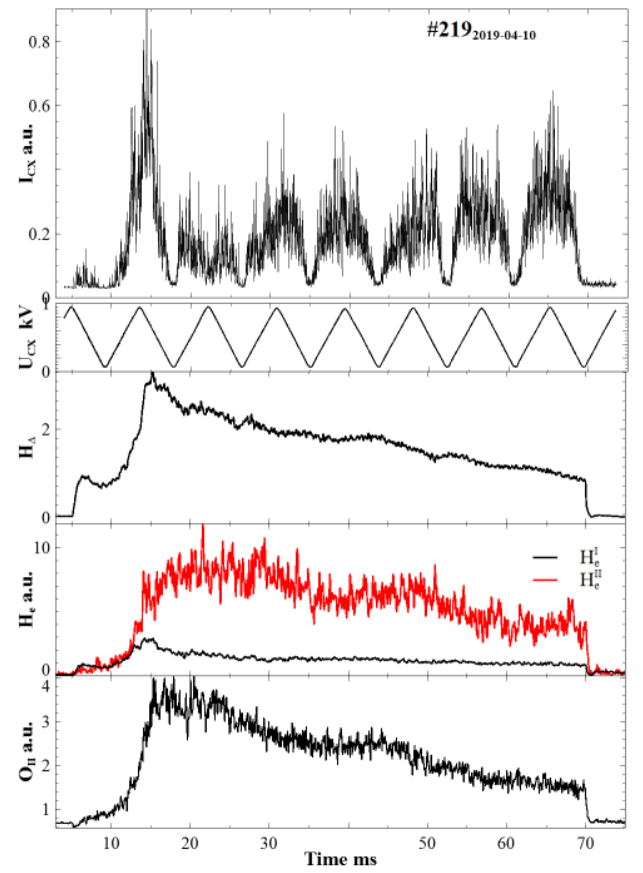

Fig. 12. Waveforms of the row NPA signal, NPA sweeping voltage, spectral lines $H_{\delta} H e^{I}, H e^{I I}$, and $O^{I I}$ emission in stellarator configuration $\mathrm{He}-\mathrm{H}$ discharge

Row NPA signal and NPA energy distribution are shown in Figs. 12, 13 correspondently. The NPA collector signal depends on the charge exchange crosssection and on the stripping efficiency on nitrogen in the NPA stripping sell. These parameters are very low for helium. It was assumed that pure hydrogen CX flux is measures for the Fig. 13 energy distribution reconstruction, therefore. However, even from row NPA data it is clear, that in this type of the discharge the ions with higher perpendicular energies are observed. The Fig. 13 data indicates that the perpendicular energy distribution is fitted well by the temperature of $0.9 \ldots 1.1 \mathrm{keV}$. In this type of discharge, the ion cyclotron zone is present in the plasma column as well.

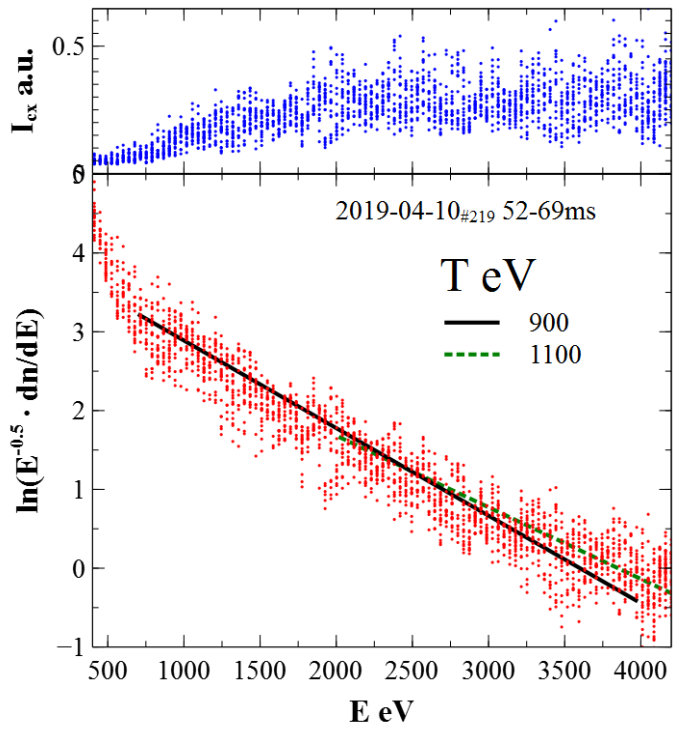

Fig. 13. Energy distribution using multiple NPA slope data in helium-hydrogen discharge

Thus, in spite of different discharge scenarios, the ion cyclotron zone is present in the plasma balk in all three discharges. We should note that with the RF generator frequency decreasing the perpendicular ion energy (and fixed $B_{0}$ ) is strongly decreasing. Single, RF-only, source of the plasma production and heating is used in U-2M. Therefore, strong dependences of all plasma parameters on the RF frequency do not allow us to separate the ion heating effect from the complex variation of the plasma conditions.

\section{CONCLUSIONS}

Dependences of the charge exchange CX neutral fluxes were investigated in three types of U-2M discharges via NPA. This CX flux corresponds to the perpendicular energy of the plasma ions. Chargeexchange neutral fluxes have been measured in plasma discharges sustained by the W7-X-like antenna. CX fluxes in pure hydrogen discharge $\left(\mathrm{B}_{0}=0.36 \mathrm{~T}\right.$, $f=4.926 \mathrm{MHz}$ ) in stellarator configuration (effective $\mathrm{CX}$ temperature $\mathrm{T}_{\perp} \approx 450 \mathrm{eV}$ ) is less energetic in comparison with U-2M hybrid configuration with disconnected toroidal field coil in vicinity of RF antenna $\left(\mathrm{T}_{\perp} \approx 800 \mathrm{eV}\right)$. RF discharge in stellarator configuration with helium and hydrogen mixture $\left(\mathrm{B}_{0}=0.351 \mathrm{~T}\right.$; $\mathrm{f}=5.156 \mathrm{MHz}$,

$\mathrm{P}=6 \cdot 10^{-4}$ Torr) can produce more energetic CX fluxes $\left(\mathrm{T}_{\perp} \approx 1 \mathrm{keV}\right)$. Numerical calculation of the ion cyclotron frequency distribution across the U-2M plasma as well as direct measurement of the RF frequency by magnetic sensor shows that the ion cyclotron frequency is present in plasma bulk of all discharges under consideration. Present work demonstrates experimental evidence of links between ion cyclotron zone and ion heating. This 
information can be used for further studies of the RF heating mechanisms of ions in U-2M stellarator.

\section{ACKNOWLEDGEMENTS}

The U-2M Team is gratefully acknowledged for providing the U-2M experimental conditions. The authors thank international Radio Frequency heating team and especially to A.V. Lozin, Yu. V. Kovtun, T. Wauters, A.I. Lyssoivan and V.E. Moiseenko for RF heating scenario development.

This work has also been supported by National Academy Science of Ukraine projects $\Pi-3 / 22-2020$, X3-19-10/2020 and A5/20-2020.

\section{REFERENCES}

1. D.W. Swain, R.H. Goulding // Fusion Eng. Des. 2007, v. 82, p. 603.

2. E. de la Cal and E. Gauthier // Plasma Phys. Control. Fusion. 2006, v. 48, p. 1455.

3. D. Douai et al // J. Nucl. Mater. 2011, v. 415, p. S1021.

4. A.I. Lysoivan, et al // Fusion Eng. Des. 1995, v. 26, p. 185.
5. M. Dreval and A.S. Slavnyj // Plasma Phys. Control. Fusion. 2011, v. 53, p. 065014.

6. M. Dreval and A.S. Slavny // Problems of Atomics Science and Technology. Series "Plasma Physics». 2010, № 6, p. 13.

7. V.E. Bykov et al // Fusion Technology. 1990, v. 17, p. 140.

8. O.S. Pavlichenko // Plasma Phys. Control. Fusion. 1993, v. 35, p. B223.

9. V.E. Moiseenko, et al. // J. of Plasma Physics. 2020, v. 86(5), p. 905860517.

10. V.V. Afrosimov et al. // Soviet Phys. Tech. Phys. 1961, v. 5, p. 1378.

11. A.V. Lozin et al. // Problems of Atomics Science and Technology. Series «Plasma Physics» (26). 2020, № 6(130), p. 10.

12. G.G. Lesnyakov et al. // Contrib. Papers of 23rd EPS Conf. on Contr. Fusion and Plasma Physics. 1996, v. 20 C, p. 547.

13. G.G. Lesnyakov et al. // Problems of Atomics Science and Technology. Series «Plasma Physics» (19). 2013, № 1(83), p. 57.

Article received 21.01.2021

\section{РАСПРЕДЕЛЕНИЕ 0,2...4,5 КЭВ ИОНОВ ПЛАЗМЫ В СЕРИИ РАЗРЯДОВ НА У-2М}

\section{А.С. Славный, Р.О. Павличенко, А.Н. Шаповал, М.Н. Махов, Н.Б. Древаль}

Поток нейтралов перезарядки измерялся анализатором нейтральных частиц в плазменных разрядах, поддерживаемых радиочастотной W7-X-подобной антенной в стеллараторе Ураган-2М (У-2M). Потоки нейтралов перезарядки в чисто водородном разряде $\left(\mathrm{B}_{0}=0,36\right.$ Тл, $\mathrm{f}=4,926$ МГц $)$ в стеллараторной конфигурации (эффективная перпендикулярная температура ионов $\mathrm{T}_{\perp} \approx 450$ эВ) менее энергичны по сравнению с условиями гибридной конфигурации У-2М ( $\mathrm{T}_{\perp} \approx 800$ эВ). ВЧ-разряд в стеллараторной конфигурации со смесью гелия и водорода $\left(\mathrm{B}_{0}=0,351\right.$ Тл; $\mathrm{f}=5,156 \mathrm{MГц,} \mathrm{P}=6 \cdot 10^{-4}$ Торр) показывает более энергичные потоки нейтралов перезарядки $\left(\mathrm{T}_{\perp} \approx 1 \kappa \ni \mathrm{B}\right)$. Численный расчёт распределения ионной циклотронной частоты в плазме У-2М, а также прямое измерение ВЧ-частоты магнитным датчиком показывают, что ионная циклотронная частота присутствует в объёме плазмы всех рассматриваемых разрядов.

\section{РОЗПОДІЛ 0,2...4,5 кеВ ІОНІВ ПЛАЗМИ В СЕРІЇ РОЗРЯДІВ НА У-2М}

\section{О.С. Славний, Р.О. Павліченко, А.М. Шаповал, М.М. Махов, М.Б. Древаль}

Потік нейтралів перезарядки вимірювався аналізатором нейтральних частинок у плазмових розрядах, що підтримуються радіочастотною W7-Х-подібної антеною у стелараторі Ураган-2М (У-2М). Потоки нейтралів перезарядки в чисто водневому розряді $\left(\mathrm{B}_{0}=0,36 \mathrm{Tл}, \mathrm{f}=4,926\right.$ МГц) у стелараторній конфігурації (ефективна перпендикулярна температура іонів $\mathrm{T}_{\perp} \approx 450 \mathrm{eB}$ ) менш енергійні в порівнянні з гібридною конфігурацією У-2М ( $\left.\mathrm{T}_{\perp} \approx 800 \mathrm{eB}\right)$. ВЧ-розряд в стелараторній конфігурації з сумішшю гелію і водню $\left(\mathrm{B}_{0}=0,351\right.$ Тл; $\mathrm{f}=5,156$ МГц, $\mathrm{P}=6 \cdot 10^{-4}$ Торр) показує більш енергійні потоки нейтралів перезарядки $\left(\mathrm{T}_{\perp} \approx 1 \kappa \mathrm{B}\right)$. Чисельний розрахунок розподілу іонної циклотронної частоти в плазмі У-2М, а також пряме вимірювання ВЧ частоти магнітним датчиком показують, що іонна циклотронна частота присутня в обсязі плазми всіх розглянутих розрядів. 